\title{
MicroRNA BIOGENESIS, FUNCTIONALITY AND CANCER RELEVANCE
}

\author{
Branislav Kusenda*, Marek Mraz, Jiri Mayer, Sarka Pospisilova*
}

Center of Molecular Biology and Gene Therapy, Department of Internal Medicine - Hematooncology, University Hospital

Brno, Černopolní 9, 62500 Brno, Czech Republic

e-mail: sarka.pospisilova@fnbrno.cz; Kusenda.Branislav@seznam.cz

Received: October 13, 2006; Accepted (with revision): November 30, 2006

Key words: MicroRNA/MiRNA/RNA interference/Cancer/CLL

Background: MicroRNAs (miRNA) are small non-coding RNAs that negatively regulate gene expression in a sequence-specific manner. Post-transcriptional silencing of target genes by miRNA occurs either by specific cleavage of homologous mRNA or by specific inhibition of protein synthesis. MiRNAs are essential regulators of various processes such as proliferation, differentiation, development, cell death and interaction between virus and host cell.

Aim: The aim of this paper is to summarize the main findings from research on miRNA biogenesis, functionality and cancer relevance.

Method: A narrative literature review of all of the relevant papers known to the authors was conducted.

Results: Several human diseases including cancer are associated with aberrant regulation of miRNAs expression or deficiency in miRNA biogenesis. Analysis of miRNA expression signatures can serve as a valuable tool for cancer classification, diagnostics and prediction of tumor behavior.

Conclusions: There has been demonstrated a possibility to use these microRNA signatures for a specific cancer classification with potential predictive and therapeutic value. The known data provide evidence that microRNAs may open new ways for cancer diagnosis, prognosis estimation and therapy.

\section{INTRODUCTION}

Recent discovery of several types of non-protein-coding RNAs, such as small nucleolar RNAs, small interfering RNAs, microRNAs and antisense RNAs indicate that the transcriptomes of higher eukaryotes are much more complex than originally anticipated. These RNAs serve as modulators of gene expression in a sequence specific manner. RNA mediated gene silencing pathways have essential roles in development, cell differentiation, cell proliferation, cell death, chromosome structure, virus resistance and oncogenesis.

MicroRNAs (miRNA) are small RNA molecules encoded in genomes of plants, animals, fungi and viruses. These highly conserved RNAs regulate gene expression by specific inhibition of translation, induction of mRNA cleavage and DNA methylation. About $1-5 \%$ of predicted genes in animals encode miRNAs and 10-30 \% of protein-coding genes are predicted targets regulated by miRNAs.

\section{THE DISCOVERY OF MICRORNA}

The first known microRNA (miRNA), the lin-4, was discovered in 1993 by Victor Ambros and his colleagues through the study of heterochronic gene lin-14 in worms. Lin-4 RNA controls the timing of Caenorhabditis elegans larval development ${ }^{1}$. It encodes a small RNA that is

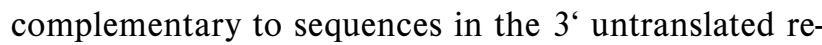

gion (UTR) of lin-14 mRNA and acts as developmental repressor of the accumulation of LIN-14 protein. This repression is essential for proper timing of numerous events of $C$. elegans larval development ${ }^{2}$. The molecular mechanism for lin-14 is temporal gradient formation: the lin-4 RNAs base pair to sites in the lin-14 3' untranslated region (UTR) to form multiple RNA duplexes that down-regulate lin-14 translation ${ }^{3}$. Translational repression of these mRNAs then triggers the transition to the next developmental stage ${ }^{3,1}$.

A second known miRNA, let-7 RNA, is expressed later in development and is complementary to the 3' untranslated regions of the heterochronic genes lin-14, lin-28, lin41 , lin-42, and $d a f-12$, indicating that the expression of these genes may be directly controlled by let-7. The lin-4 and let-7 are nonhomologous and act in a similar manner to trigger the transition to late-larval and adult stages ${ }^{4}$. Recent studies suggest that let-7 is a tumor suppressor ${ }^{5}$.

A study from Ruvkun's group provided the first evidence that gene regulation mediated by small RNAs of 22-nucleotides may exist in species beyond worms. They found that let-7 RNA expression can be detected in a wide range of animal species, including vertebrate, ascidian, hemichordate, mollusc, annelid and arthropod, further implying that small RNA-mediated translational regulation may be a widespread gene regulatory model present in many animal species ${ }^{6}$.

Each miRNA is thought to regulate multiple genes, hundreds of miRNA genes are predicted ${ }^{7}$ and several hundreds have been cloned and sequenced from $C$. elegans, 
Drosophila, Arabidopsis, mice and human (see http://microrna.sanger.ac.uk $)^{8}$. The large number of miRNAs and homologous sequences of many miRNAs among organisms suggests that these RNAs might constitute an abundant component of the gene regulatory machinery with an ancient origin ${ }^{9}$.

\section{BIOGENESIS OF MIRNAS}

Although they may differ in detail in animals, plants and fungi, the basic process involves a transcription of dsRNA that is processed into shorter units that mediate target recognition in a sequence specific manner ${ }^{10}$. Both biogenesis and action of miRNAs rely on components of the RNA interference (RNAi) machinery, but miRNAs differ from small interfering RNAs (siRNAs) in several aspects. MiRNAs are generally conserved in evolution, they direct the silencing of genes that are unrelated to the loci encoding the miRNAs themselves and each miRNA comes from a gene that is dedicated to production of a particular 22 nucleotide RNA ${ }^{11}$.

Analysis of 186 miRNA genes provides information about the nonrandom distribution of miRNA genes in the human genome. Ninety miRNA genes are located in 36 clusters, usually with two or three genes per cluster (median 2.5) ${ }^{12}$. The largest cluster is composed of seven miRNA genes ${ }^{13}$. Recent findings of intron-derived miRNA in C. elegans, mouse and human have inevitably led to an alternative pathway for miRNA biogenesis, which relies on the coupled interaction of Pol-II-mediated pre-mRNA transcription and intron excision. Some of the spliced introns become aberrant RNAs and are further cleaved by certain RNase or complementing-repair complexes to form miRNA-like molecules. After splicing, approximately $10-30 \%$ of the introns are found in the cytoplasm with a moderate half-life, which is long enough to execute extra functions ${ }^{14}$. Analyses have shown that human primary miRNA transcripts (pri-miRNAs) contain cap structures as well as poly(A) tails, ${ }^{15}$ which are the unique

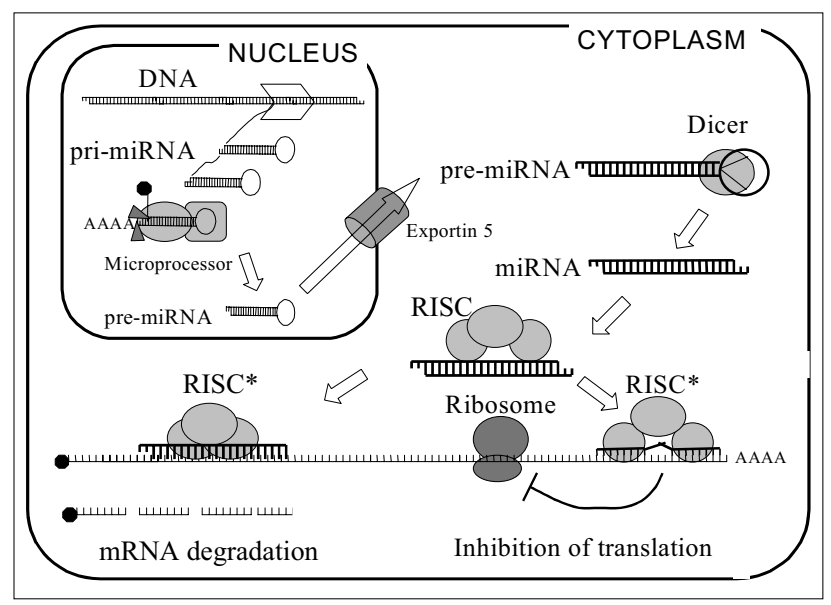

Fig. 1. Biogenesis of microRNA and two possible mechanisms of function. properties of class II gene transcripts. These data indicate that pol II is the main RNA polymerase for miRNA gene transcription $^{16}$. Animal miRNAs are initially transcribed as part of one arm of an about 70 nucleotide RNA stemloop that in turn forms part of a several hundred nucleotides long miRNA precursor termed a primary miRNA (pri-miRNA) ${ }^{17}$ (see Fig. 1).

After transcription, next step in miRNA biogenesis is the excision of the upper part of this RNA hairpin by the nuclear enzymatic complex Microprocessor including Drosha (RNase III enzyme) and DGCR8 (dsRNA binding protein) to produce an 65-nt intermediate, termed a pre-miRNA ${ }^{18}$. Pre-miRNAs, which form short RNA hairpins bearing a 2-nt 3'overhang, are then bound by the nuclear export factor Exportin 5, which transports them to the cytoplasm ${ }^{19}$. Here, a second RNase III enzyme termed Dicer removes the terminal loop of the pre-miRNA to generate an 20-bp RNA duplex with 2-nt 3'overhangs ${ }^{20}$. The mature miRNA, which forms one strand of this duplex, is then incorporated into a large protein complex, termed the RNA induced silencing complex (RISC), where it functions to guide RISC to target mRNA ${ }^{21 ; 22}$. RISC than can inhibit the translation of mRNA bearing partially complementary target sequences ${ }^{23}$.

\section{POST-TRANSCRIPTIONAL REPRESSION BY MIRNAS}

MiRNAs regulate gene expression at post-transcriptional level by specific inhibition of translation or induction of mRNA cleavage. MiRNA duplexes are incorporated into the protein complex RISC ${ }^{24}$ and, after unwinding, they remodel the complex to generate an active RNA induced silencing complex (RISC *) ${ }^{25}$. Multiple miRNAs might need binding to a particular untranslated region to achieve repression, which could be accomplished by the combinatorial action of different miRNA species ${ }^{11}$. This suggests that expression of miRNA target genes can be fine-tuned in animals (and potentially in plants) by altering concentrations or identities within cells ${ }^{23,26}$. An important difference is that the plant miRNAs are more perfectly paired to their target RNA and use RNA cleavage rather than translation suppression as the primary silencing mechanism ${ }^{27}$. Whereas perfect complementarity with targets was found in plants, in animals the identification of putative targets is much more complicated, because bulges and loops are not only tolerated, but seem to be the rule. Despite the overall imperfect complementarity, a large subset of Drosophila miRNAs were shown to be precisely complementary to the $\mathrm{K}$ box, Brd box and GY box motifs in the 3' untranslated region (UTR), motifs found to significantly affect both transcript stability and translational efficiency ${ }^{28}$. The animal miRNAs are normally targeted to the 3'UTR of mRNA $^{29}$, whereas the plant miRNAs have targets in the coding sequence or even in the ${ }^{\text {' }} \mathrm{UTR}^{30} . \mathrm{M}^{7} \mathrm{G}$-cap-independent translation is not subject to repression, suggesting that miRNPs interfere with 
Table 1. Tissue-specific miRNA expression signatures.

\begin{tabular}{|l|l|}
\hline \multicolumn{1}{|c|}{ Expression pattern } & \multicolumn{1}{c|}{ MicroRNA } \\
\hline Enriched in brain & $\begin{array}{l}m i R-12 a, m i R-125 b, m i R-128, m i R-132, m i R-139, m i R-7, m i R-9, m i R-124 a, \\
m i R-124 b, m i R-135, m i R-153, m i R-149, m i R-183, m i R-190, m i R-219\end{array}$ \\
\hline Enriched in lung & $\begin{array}{l}m i R-18, m i R-19 a, m i R-24, m i R-32, m i R-130, m i R-213, m i R-20, m i R-141, m i R-193, \\
m i R-200 b\end{array}$ \\
\hline Enriched in spleen & $m i R-99 a, m i R-127, m i R-142 a, m i R-142 s, m i R-151, m i R-189, m i R-212$ \\
\hline Enriched in liver & $m i R-122 a, m i R-152, m i R-194, m i R-199, m i R-215$ \\
\hline Enriched in heart & $m i R-1 b, m i R-1 d, m i R-133, m i R-206, m i R-208, m i R-143$ \\
\hline Enriched in kidney & $\begin{array}{l}m i R-30 b, m i R-30 c, m i R-18, m i R-20, m i R-24, m i R-32, m i R-141, m i R-193, \\
m i R-200 b\end{array}$ \\
\hline Enriched in haematopoetic tissues & $m i R-181, m i R-223, m i R-142$ \\
\hline Ubiquitously expressed & $m i R-16, m i R-26 a, m i R-27 a, m i R-143 a, m i R-21$, let-7a, miR-7b, miR-30b, miR-30c \\
\hline
\end{tabular}

recognition of the cap. Repressed mRNAs, Ago proteins (RNA-binding proteins, member of RISC) and miRNAs were all found to accumulate in processing bodies (P-bodies) for storage. MiRNAs and proteins associated with them also localize to P-bodies, underscoring an important role for these structures in switching on and off eukaryotic gene expression ${ }^{31}$. In mammalian tissue cultures, a short interfering RNA (siRNA) can repress expression of a target mRNA with partially complementary binding sites in its 3' UTR, in a very similar manner as endogenously encoded microRNAs (miRNAs). The discovery that siRNAs can function in translational repression as miRNAs and that the sequence requirements for this interaction are less stringent than those for RNAi, may help to explain nonspecific effects sometimes observed in experiments using siRNAs for targeted gene silencing ${ }^{32}$. MiRNAs and siRNAs are capable of triggering either translation repression or mRNA degradation depending on the degree of complementarity and homology with their target genes. The choice of mechanism may be largely or entirely determined by the degree of complementary of the RNA target $^{23}$ (see Fig. 1).

\section{MIRNAS REGULATE DIFFERENTIATION, DEVELOPMENT AND CELL DEATH}

Knight and Bass described a null mutation in dicer-1 (dcr- 1 ) and found that $d c r-1(-/-)$ C. elegans have defects in RNAi under some, but not all, conditions. Mutant animals have germ line defects that lead to sterility ${ }^{33}$. Inactivation of genes related to RNAi pathway causes heterochronic phenotypes similar to lin-4 and let-7 mutations $\mathrm{s}^{34}$. These findings suggest that miRNas have an essential role in $C$. elegans embryogenesis and larval development.

To block all miRNA formation in zebrafish, there were generated maternal-zygotic dicer (MZdicer) mutants that disrupt the Dicer ribonuclease III and double-stranded RNA-binding domains. Mutant embryos do not process precursor miRNAs into mature miRNAs. MZdicer mutants undergo axis formation and differentiate multiple cell types but display abnormal morphogenesis during gastrulation, brain formation, somatogenesis and heart development ${ }^{35}$. Zebrafish miR-430 is expressed at the onset of zygotic transcription and regulates morphogenesis during early development. Most targets are maternally expressed mRNAs that accumulate in the absence of $m i R-430$. Injection of $m i R-430$ miRNAs rescues the brain defects in MZdicer mutants, revealing essential roles for miRNAs during morphogenesis ${ }^{36}$.

The Drosophila microRNA miR-14 suppresses cell death and is required for normal fat metabolism. Loss of $m i R-14$ enhances Reaper-dependent cell death, whereas ectopic expression suppresses cell death induced by multiple stimuli. MiR-14 also regulates fat metabolism. Deletion of miR-14 results in animals with increased levels of triacylglycerol and diacylglycerol, whereas increases in miR-14 copy number have the converse effect ${ }^{37}$.

Results from microarrays experiments revealed tissue-specific miRNA expression signatures. Different tissues have distinctive patterns of miRNome expression (defined as the full complement of miRNAs in a cell) (see Tab. 1) ) $^{38,39,40,41 \text {, }}$.

\section{RNA-DIRECTED DNA METHYLATION, HISTON MODIFICATIONS AND CHROMATIN REMODELING}

The first evidence that RNA can trigger cytosine methylation of identical genomic DNA sequences came from experiments using RNA viroids, short circular infectious RNA species with a high degree of secondary structure, present in tobacco. It was shown, that de novo 
methylation of genes can be induced and targeted in a sequence-specific manner by $\mathrm{RNA}^{42}$. In plants and yeast there is also evidence that miRNAs are involved in repression of transcription by chromatin methylation ${ }^{43}$. For instance in Arabidopsis, both DNA methylation and histone H3 Lys9 methylation require the RNAi machinery ${ }^{44}$. Recent findings that RNAi-mediated silencing pathways play a role in heterochromatin assembly ${ }^{45}$ have reshaped the way we think about heterochromatin formation and epigenetic maintainance (see Fig. 2). Evidence suggests that RNA, in particular double stranded RNA produced from transgenes or repeats, is able to induce heterochromatin assembly at homologous sequences in trans. RNA provides specificity for precise targeting of silent chromatin complexes to particular genomic loci ${ }^{43}$.

\section{MIRNA AND VIRUSES}

Recently, many viral-encoded miRNAs have been discovered, for the most part in viruses transcribed from double-stranded DNA genomes. As with their cellular counterparts, the functions of most viral-derived miRNAs are unknown; however, functions have been documented or proposed for viral miRNAs from three different viral families - herpesviruses, polyomaviruses and retroviruses ${ }^{46}$. Approximately 40 miRNAs and $10 \mathrm{RNAi}$ suppressors encoded by diverse mammalian viruses have been identified ${ }^{47}$. Viral evolution has taken advantage of the miRNA pathway to generate effectors that enhance the probability of successful infection ${ }^{48}$.

Epstein-Barr virus (EBV) is a large DNA virus of the Herpesviridae family that preferentially infects human $\mathrm{B}$ cells and this virus expresses several microRNA genes. The small RNA profile of cells infected by EBV was recorded and there was discovered that EBV miRNAs originated from five different double-stranded RNA (dsRNA) precursors clustered in two regions of the EBV genome. Epstein-Barr virus use RNA silencing as a method for gene regulation of host and viral genes in a non-immunogenic manner ${ }^{49}$.

Dunn et al. (2005) reported that human cytomegalovirus (HCMV) expresses miRNAs during its productive lytic infection of four clinically relevant human cell types. The sequences of the miRNAs, expressed from the

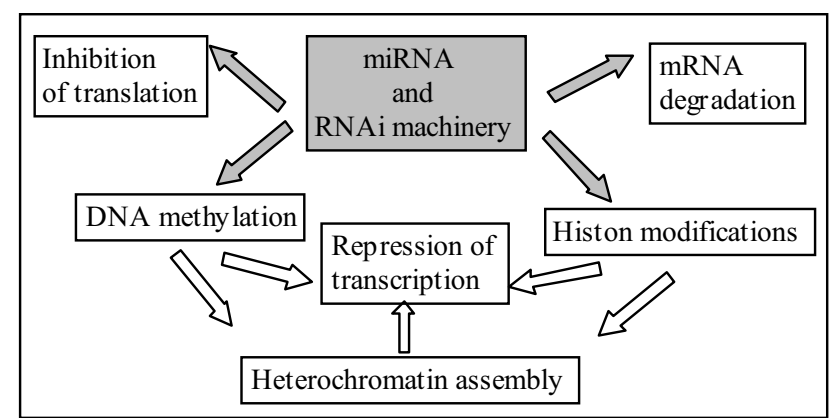

Fig. 2. MicroRNAs regulate gene expression and heterochromatin assembly.
UL23 and US24 loci of the viral genome, were conserved among all HCMV strains examined and in chimpanzee cytomegalovirus $^{50}$. HCMV encodes multiple conserved miRNAs and suggests that human cytomegalovirus may utilize a miRNA strategy to regulate cellular and viral gene function ${ }^{51}$.

The simian virus 40 (SV40) encodes miRNAs that are significant for viral infection. These miRNAs accumulate at late times in infection, are perfectly complementary to early viral mRNAs and target those mRNAs for cleavage. This reduces the expression of viral $\mathrm{T}$ antigens ${ }^{48}$.

Using computer-directed analyses, Bennasser et al. (2004) found that HIV-1 putatively encodes five candidate pre-miRNAs and suggested that a large number of cellular transcripts could potentially be targeted if these 5 pre-miRNAs were processed into 10 predicted mature miRNAs $^{52}$.

The small size of miRNA precursors makes them also potentially ideal for use by oncogenic viruses as inhibitors of host cell defense pathways. Kaposi's sarcoma-associated herpesvirus encodes 11 distinct miRNAs, which are expressed in infected cells ${ }^{53}$. Some of oncogenic viruses use miRNA genes as a preferred integration site. Human Papilloma Virus 16 (HPV16), associated with cervical cancer, integrates into miRNA genes at a rate 3 times higher than to the rest of the genome ${ }^{12}$.

Cellular microRNAs have regulatory functions and direct antiviral effects. A cellular microRNA effectively restricts the accumulation of the retrovirus primate foamy virus type 1 (PFV-1) in human cells. Viral Tas protein suppresses microRNA-directed functions in mammalian cells and displays cross-kingdom antisilencing activities ${ }^{54}$. Infection of Arabidopsis by Turnip mosaic virus (TuMV) induces a number of defects in vegetative and reproductive organs. Kasschau and colleagues (2003) found that these defects, many of which resemble those in miRNA-deficient dicer-likel (dcll) mutants, were due to the TuMV encoded RNA-silencing suppressor, P1/HC-Pro. Suppression of RNA silencing is a counterdefensive mechanism that enables systemic infection by TuMV. Interference with miRNA-guided functions by plant viruses may explain why certain viruses cause developmental abnormalities during infection ${ }^{55}$. Chen et al. (2004) described a virulence factor encoded by turnip yellow mosaic virus, p69, which suppresses the antiviral siRNA pathway but promotes the miRNA pathway in Arabidopsis thaliana. p69 suppression of the siRNA pathway is upstream of dsRNA and is as effective as genetic mutations in A. thaliana genes involved in dsRNA production. p69-expressing plants exhibited disease-like symptoms in the absence of viral infection, these findings suggest a novel mechanism for viral virulence by promoting the miRNA-guided inhibition of host gene expression ${ }^{56}$.

Experimental expression of a geminivirus-encoded AC4 protein from African cassava mosaic virus Cameroon Strain (ACMV) in transgenic plants provides direct evidence that AC4 protein is a unique virus-encoded posttranscriptional gene-silencing suppressor protein. It binds to and presumably inactivates mature miRNAs ${ }^{57}$. 
Table 2. MicroRNAs associated with cancer diseases.

\begin{tabular}{|c|c|}
\hline Cancer type & Aberrantly regulated microRNAs \\
\hline CLL - chronic lymphocytic leukemia (CLL) & $\begin{array}{ll}\text { o } & m i R-15 a \text { and } m i R-16-1, \text { down-regulated in more than } \\
& 60 \% \text { of CLL cases } \\
\text { o } & m i R-155 / \text { BIC RNA, increased levels } \\
\text { o } & m i R-17-92 \text { cluster, only some members are abnormally } \\
& \text { expressed } \\
\text { o } & \text { miR-213, miR-183, miR-190, miR-24-1, miRNAs lo- } \\
& \text { cated exactly inside fragile sites } \\
\text { o } & m i R-96, \text { miR-182, miR-183= } 7 \mathrm{q} 32 \text { group, all members } \\
& \text { are aberrantly regulated } \\
\text { o } & \text { and many others }{ }^{8} \text { (see Calin } \text { et al., 2004) }\end{array}$ \\
\hline $\begin{array}{l}\text { CLL - distinguish CLL samples that express unmutated } \\
\text { IgVh gene from those that express mutated IgVh gene }\end{array}$ & $\begin{array}{l}\text { miR-186, miR-132, miR-16-1, miR-102(miR-29) } \\
\text { and } m i R-29 c\end{array}$ \\
\hline $\begin{array}{l}\text { CLL - } 13 \text { miRNAs prognostic group, could discrimi- } \\
\text { nate between CLL samples that express ZAP- } 70 \text { and } \\
\text { unmutated IgVh and CLL samples that have no expres- } \\
\text { sion of ZAP and have a mutated IgVh }\end{array}$ & $\begin{array}{l}m i R-15 a, m i R-195, m i R-223, m i R-24-1, m i R-29 b-2, \\
m i R-29 a-2, m i R-16-1, m i R-16-2, m i R-155, m i R-146 \\
m i R-221, m i R-23 b \text { and } m i R-29 c\end{array}$ \\
\hline $\begin{array}{l}\text { CLL - } 9 \text { miRNAs predicting interval from diagnosis to } \\
\text { therapy, differentiate patients with a short interval from } \\
\text { diagnosis from patients with a longer interval }\end{array}$ & $\begin{array}{l}m i R-155, m i R-146, m i R-221, m i R-23 b, m i R-29 c \\
m i R-222, m i R-24-2, m i R-23 a \text { and } m i R-181 a\end{array}$ \\
\hline $\begin{array}{l}\text { diffuse large B cell lymphoma, marginal zone } \\
\text { lymphomas, other non-Hodgkin lymphomas } \\
\text { and Hodgkin lymphomas }\end{array}$ & miR-155/ BIC RNA, increased levels \\
\hline aggressive B cell leukemia & $\begin{array}{l}\text { miR-142 translocation } \mathrm{t}(8,17) \text { causes up-regulation of } \\
\text { a translocated } c-M Y C \text { gene }\end{array}$ \\
\hline breast cancer & $\begin{array}{ll}\text { o } & m i R-10 b, m i R-125 b \text { and } m i R-145 \text {, down-regulated } \\
\text { o } & m i R-21 \text { and } m i R-155 \text {, up-regulated }\end{array}$ \\
\hline lung cancer & $\begin{array}{ll}\text { o } & \text { let-7, reduced expression } \\
\text { o } & m i R-155, \text { over-expression } \\
\text { o } & m i R-17-92 \text { cluster, over-expression } \\
\end{array}$ \\
\hline glioblastoma & $\begin{array}{ll}\text { o } & m i R-221, m i R-21, \text { strongly over-expressed } \\
\text { o } & m i R-128, m i R-181 a, m i R-181 b \text { and } m i R-181 c, \\
& \text { down-regulated }\end{array}$ \\
\hline colorectal tumors & $m i R-143$ and $m i R-145$, down-regulated \\
\hline $\begin{array}{l}\text { for chromosomal location of microRNAs see: } \\
\text { http://microrna.sanger.ac.uk }\end{array}$ & $\begin{array}{l}\text { miR-17-92 cluster: } m i R-17-5 p, m i R-17-3 p, m i R-18 \\
m i R-19 a, m i R-20, m i R-19 b 1, m i R-92-1\end{array}$ \\
\hline
\end{tabular}

The first known viral gene product able to inhibit RNAi in human cells was highly structured $\sim 160$-nucleotide adenoviral VA1 noncoding RNA. Inhibition appeared to be due both to inhibition of nuclear export of shRNA or pre-miRNA precursors, competition for the Exportin 5 nuclear export factor and inhibition of Dicer function by direct binding of Dicer ${ }^{58}$.

\section{MIRNAS AND HUMAN DISEASE}

Several human diseases have been pinpointed in which miRNAs or their processing might be implicated. One of them is Spinal muscular atrophy (SMA), a paediatric neurodegenerative disease caused by reduced protein level or loss-of-function mutation of the survival of motor neuron gene $(S M N)$. Two proteins (Gemin 3 and Gemin 4) that are part of the SNM complex are also components of miRNPs, whereas it remains to be seen whether miRNA biogenesis or/and function is deregulated in SMA and what effect has this fact on pathogenesis ${ }^{59}$. Another neu- 
rological disease in which miRNAs or their processing machinery have been included, is fragile X mental retardation (FXMR) caused by absence or mutation of the fragile X mental retardation protein. Experimental results from Drosophila melanogaster indicate that FXMR may be a part of RISC ${ }^{60}$. Example of disease, in which miRNA processing might be also implicated, is the DiGeorge syndrome, the most common human genetic deletion syndrome. The clinical manifestation of this disease is highly variable, from heart defects to schizophrenia. The deletion region includes about 30 genes; one is the $D G C R 8$ component of the Microprocessor complex ${ }^{61}$. MiR-224 gene locus lies within the minimal candidate region of two diferent diseases: X-linked mental retardation and earlyonset Parkinson's disease ${ }^{59}$. Over-expression of $m i R-375$ suppresses glucose-induced insulin secretion and could represent a novel pharmacological target ${ }^{62}$.

\section{MICRORNAS AND CANCER}

Among human diseases, it has been shown that miRNAs are aberrantly expressed in cancer, suggesting that they may play a role as a novel class of oncogenes or tumor suppressor genes (see Fig. 3).

The findings that miRNAs have a role in cancer are supported by the fact that about $50 \%$ of miRNA genes are localised in cancer-associated genomic regions or in fragile sites ${ }^{12}$. The predicted number of miRNAs in the human genome is as many as 1000 (i.e. 1-5\% of the predicted genes in the genome). Regulation mediated by these genes has possibly a large impact on gene expression because, according to computional predictions, a single miRNA can target dozens of genes. Many authors have reported that each cancer tissue has a specific microRNA signature and microRNA based cancer classification is a very effective and potential tool ${ }^{63}$.

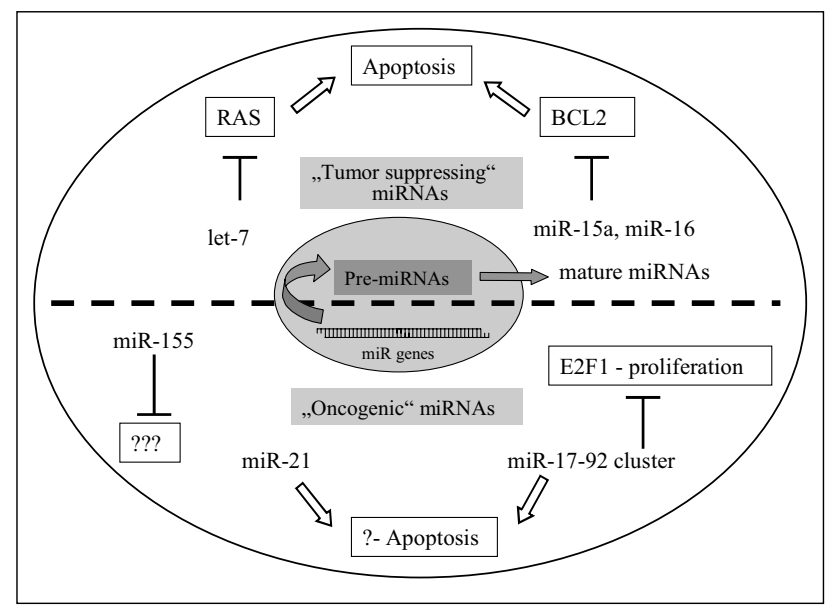

Fig. 3. Possible "tumor suppressing" and "oncogenic" miRNAs.

\section{HEMATOLOGICAL MALIGNANCIES}

The first evidence of the involvement of miRNAs in cancer came from molecular studies characterizing the $13 q 14$ deletion in human chronic lymphocytic leukemia (CLL). Deletion of the $13 \mathrm{q} 14$ region occurs in more than half of the cases of B cell chronic lymphocytic leukemias and also in $50 \%$ of mantle cell lymphomas, in 16-40\% of multiple myelomas and in $60 \%$ of prostate cancers, suggesting that tumor suppressor(s) gene(s) at $13 q 14$ are involved in the pathogenesis of these tumors ${ }^{64,65,66,67}$. Calin et al. (2002) have shown that two miRNA genes are located at $13 \mathrm{q} 14.3$ within a $30-\mathrm{kb}$ region of minimal loss in CLL between two exons of the LEU2 gene. Both of these genes, $m i R-15 a$ and $m i R-16-1$, are down-regulated in more than $60 \%$ of CLL cases (detected using Northern blot analyses $)^{68}$. A very similar cluster ( $m i R-15 b$, $\left.m i R-16-2\right)$, but with a different promoter, was found on chromosome $3 q 25-26.1^{69}$. It seems that these miRNAs are less intensively expressed in normal cells ${ }^{68}$, but may play a role in cases of $13 \mathrm{q} 14$ deletions. Cimmino et al. have demonstrated a possible target for $m i R-15 a$ and $m i R-16-1$, when they uncovered that both miRNAs negatively regulate BCL2 at a posttranscriptional level and their expression is inversely correlated to BCL2 expression in CLL. Moreover, in a leukemic cell line model, BCL2 repression by these microRNAs induces apoptosis ${ }^{70}$. Deregulation of antiapoptotic BCL2 in CLL cells seems to be a key event in cancerogenesis.

Recently, it has become possible to analyze the entire miRNome by microarrays containing all known human miRNAs. The use of miRNA microarrays has made it possible to confirm miR-16 deregulation in human CLL and also recognize miRNA expression signatures associated with defined clinicopathologic features. $m i R-16-1$ and $m i R-15 a$, which were previously reported to be down-regulated in the majority ( $68 \%$ ) of CLL cases by Northern analysis, were found to be expressed at low levels in $45 \%$ (miR-16-1) and in $25 \%$ (miR-15a) of CLL samples ${ }^{71}$. These findings, that down-regulation of $m i R-16-1$ and $m i R-15 a$ expression correlates with allelic loss at $13 \mathrm{q} 14$, may be important for clinical classification of CLL. Patients with a normal karyotype or deletion of $13 \mathrm{q} 14$ as the sole genetic abnormality have a better prognosis than those with a complex karyotype or frequent deletion of 11q23 or $17 \mathrm{p} 13^{53,72,73}$. Expression profiling of miRNAs in human B-CLL has identified significant differences in miRNome expression between CLL samples and normal CD5+ B lymphocytes. At the top of list of differently expressed miRNAs are several miRNAs located exactly inside fragile sites. In some miRNA genomic clusters all members are aberrantly regulated. In others only some members were abnormally expressed such as the $13 \mathrm{q} 31$ genomic cluster ${ }^{71}$ (see Tab. 2), which is the largest known miRNA cluster, composed of seven genes (miR-17-92 cluster) $)^{13}$. Two miRNA expression clusters in CLL samples that associate with the presence ( $20 \%$ as a cutoff) or absence of Zap70 expression $^{71}$, could be identified. ZAP-70 is a tyrosine kinase and low level of its expression is a predictor as- 
sociated with good prognosis ${ }^{74,75}$. Moreover, five differentially expressed miRNAs distinguish CLL samples that express unmutated IgVh locus from those that express mutated IgVh locus - a favorable prognostic factor ${ }^{71}$ (see Tab. 2). A signature composed of 13 microRNAs could well discriminate between a group of CLL samples that expresses ZAP-70 and unmutated IgVh (patients with worse prognosis) and the group that has no expression of ZAP and mutated IgVh (patients with better prognosis) (see Tab. 2). Furthermore, members of the 13-member prognostic signature can well differentiate patients with a short interval from diagnosis to initial treatment (treatment begins with the development of the symptomatic or progressive disease) from patients with a longer interval ${ }^{76}$ (see Tab. 2). To summarize, the miRNA expression profile is associated with progression in CLL and can serve as a possible prognostic marker.

Following the initial finding about $m i R-15$ and $m i R-16$, miRNA expression deregulation has been proven in other tumors. The analyses of lymphoma samples and cell lines showed that an elevation in the amount of $m i R-155 / \mathrm{BIC}$ RNA occurs in a wide range of lymphomas derived from $B$ cells. Increased miR-155 levels (2,000-10,000 copies per cell vs. 150 in normal circulating B cells) were observed in diffuse large B cell lymphoma (DLBCL), CLL, marginal zone lymphomas and in other non-Hodgkin and Hodgkin lymphomas ${ }^{77}$. Thus, miR-155 may play a role in the pathogenesis of B cell lymphomas in general. In clinical isolates of DLBCL, higher levels of miR-155 were present in cells with the activated $B$ cell phenotype (patients with worse prognosis) than in cells with the germinal center phenotype (patients with better prognosis). The levels of $m i R-155$ (and BIC RNA) appear to correspond with clinically significant subtypes of DLBCLs and quantification of miR-155 levels may be a useful prognostic marker ${ }^{77}$.

Microarray-based expression studies have indicated another specific alterations in human miRNA expression profiles that correlate with B cell lymphomas. It was found that levels of the primary or mature microRNAs derived from the $m i R-17-92$ locus are often substantially increased in these cancers ${ }^{13}$ (see Tab. 2). The miR-17-92 cluster is located at $13 \mathrm{q} 31.3$, a genomic locus that is amplified in cases of diffuse large B-cell lymphoma, follicular lymphoma, mantle cell lymphoma, primary cutaneous Bcell lymphoma and other tumour types ${ }^{78,79}$. The transcript of this cluster appears to be the functional precursor of seven important microRNAs. Co-expression of the miR17-92 cluster acted with c-myc expression to accelerate tumour development in a mouse B-cell lymphoma model ${ }^{13}$. O'Donnell et al. (2005) discovered that c-Myc negatively regulates the transcription of $m i R-17-92$ cluster and binds directly the genomic locus encoding these miRNAs. Deregulated expression or function of c-Myc is one of the most common abnormalities in human malignancy. They also showed that two miRNAs of $m i R-17-92$ cluster ( $m i R$ $17-5 p$ and $m i R-20 a$ ) target an important proproliferative /proapoptotic transcription factor $\mathrm{E} 2 \mathrm{~F} 1^{80}$. This cluster is also overexpressed in lung cancers, especially in the most agressive small-cell lung cancer ${ }^{81}$.
Another miRNA located at a site of rearrangement linked to human leukemia is $m i R-142$, whose gene is at the breakpoint junction of a $\mathrm{t}(8 ; 17)$ translocation, which causes an aggressive $\mathrm{B}$ cell leukemia due to up-regulation of a translocated $c-M Y C$ gene $^{69,82,83}$. Chen et al. (2004) have studied the role of miRNAs in hematopoietic lineage differentiation (mouse model) and have found that miR-142 expression is higher in B-lymphoid and myeloid lineages compared to other hematopoetic tissues. They were also able to identify several miRNAs that are specifically expressed and dynamically regulated during early hematopoiesis (miR-181 and $m i R-223)^{83}$.

\section{COLORECTAL NEOPLASIA}

At the adenomatous and cancer stages of colorectal neoplasia mature miRNAs, miR-143 and miR-145 consistently display reduced levels in cells. Northern blot analyses have shown that these miRNAs are down-regulated also in cell lines derived from breast, prostate, cervical and lymphoid cancers as well as colorectal tumors. Altered transcription occurs despite the maintenance of constant levels of unprocessed hairpin precursors in both normal and tumor tissues, suggesting that this reduction is due to posttranscriptional processes ${ }^{84}$.

\section{BREAST CANCER}

miRNAs are also aberrantly expressed in human breast cancer. Among the differentially expressed miRNAs, $m i R-10 b, m i R-125 b, m i R-145, m i R-21$ and $m i R-155$ emerged as the most consistently deregulated in breast cancer. Two of them, $m i R-21$ and $m i R-155$, were up-regulated ${ }^{85}$ and the remaining three were down-regulated. $m i R-125 b$ gene is located at chromosome 11q23-24, one of the regions most frequently deleted in breast, ovarian, and lung tumors $^{86,87}$ and it appears to be a putative homologue of lin-4 in Caenorhabditis elegans ${ }^{88}$. It was possible to identify miRNAs whose expression was correlated with specific breast cancer biological features, such as tumor stage, vascular invasion or lymph node metastasis. $m i R-145$ was progressively down-regulated from normal breast tissue to cancer with high proliferation index. Similarly, but in opposite direction, $m i R$ - 21 was progressively up-regulated from normal breast tissue to cancers with high tumor stage. $m i R-9-3$ was down-regulated in breast cancers with either high vascular invasion or presence of lymph node metastasis. The expression of various let-7 miRNAs was down-regulated in breast cancer samples with either lymph node metastasis or higher proliferation index ${ }^{85}$.

\section{LUNG CANCER}

In lung cancer has been shown for the first time that alterations in the miRNA expression may have a direct prognostic impact. let-7 expression is frequently reduced 
in lung cancers and this is associated with decreased postoperative survival ${ }^{89}$. In another study, high miR-155 and low let-7a-2 expression correlated with poor survival of lung adenocarcinomas ${ }^{90}$. An in vitro experiment has demonstrated that overexpression of let-7 results in the inhibition of lung cancer cell growth ${ }^{89}$. Expression of this miRNA is lower in lung tumors than in normal lung tissue, while RAS protein is significantly higher in lung tumors, providing a possible mechanism for let-7 as a negative regulator of the RAS oncogene family ${ }^{91}$. Moreover, Dicer protein expression is reduced in a fraction of lung cancers with a prognostic impact on the survival of surgically treated patients ${ }^{92}$.

\section{GLIOBLASTOMA}

The analysis of both glioblastoma tissues and glioblastoma cell lines enabled the identification a group of microRNAs whose expression is altered in this frequent malignant primary brain tumor. Two miRNAs, $m i R-221^{93}$ and $m i R-21$ are strongly over-expressed in glioblastoma. $m i R-21$, knockdown in cultured glioblastoma cells, triggers activation of caspases and leads to increased apoptotic cell death ${ }^{94}$. This miRNA is also up-regulated in breast cancer $^{85}$, suggesting that its gene target(s) belong(s) to the class of tumor suppressors. Additionaly, a group of brain-enriched miRNAs, miR-128, miR-181a, miR-181b, and $m i R-181 c$, were down-regulated in glioblastoma ${ }^{93}$. Genes encoding microRNAs that were found to be modulated in glioblastoma, do not reside in chromosomal locations commonly deleted, amplified or rearranged in this type of brain tumor ${ }^{95,96}$. This is in contrast with other miRNAs whose position is very often located in common regions of deletion or chromosomal rearrangements. The concurrent down-regulation of $m i R-181 a, b$ and $c$ occurs probably due to modulation of their expression rather than to rearrangements or deletions because they are located on three distinct chromosomes ${ }^{7,97}$.

\section{CONCLUSION}

It is becoming clear that microRNAs play a very important role in regulation of gene expression. They are expressed at high levels in animal cells and are dynamically regulated during cell differentiation, apoptosis, proliferation, development and metabolism. MicroRNAs probably constitute as many as about 1000 miRNA genes in human genome and have a specific microRNA signature in each normal or cancer cell type. There has been demonstrated a possibility to use these microRNA signatures for a specific cancer classification with potential predictive and therapeutic value. MicroRNAs are aberrantly expressed in all studied cancer tissues, are located in cancer-associated genomic regions and their putative targets are very often tumor suppressors or oncogenes. For instance miRNAs $m i R-17-92, m i R-155, m i R-21$, whose expression is enhanced in tumors, might be considered as oncogenes and their targets as tumor suppressors. Under-expressed miRNAs, such as let-7, probably act as tumor-suppressor genes and their modulation more likely reflects the loss of differentiation typical for tumor cells (Fig. 3). Substantial number of eukaryotic microRNAs has to be discovered and identification of their target genes is a big challenge for bioinformatics and molecular biologists because of their imperfect base-pairing with the target mRNA. The known data provide evidence that microRNAs may disclose new ways for cancer diagnosis, prognosis estimation and therapy.

\section{ACKNOWLEDGEMENTS}

We thank to Dr. Richard Zelenka for critical reading of the manuscript. The work was supported by grant IGA MZ ČR NR8448-3/2005.

\section{GLOSSARY OF TERMS}

AC4 protein - Geminivirus-encoded protein.

ACMV - African cassava mosaic virus.

Ago proteins - Argonaute proteins, RNA binding proteins with endonuclease activity, members of RISC.

CLL - B cell chronic lymphocytic leukemias.

Cosuppression - Silencing of an endogenous gene caused by the introduction of a transgene or infection by a virus. This term, which can refer to silencing at the post-transcriptional (PTGS) or transcriptional (TGS) level, has been primarily adopted by researchers working with plants.

dcl1 - Dicer-like1.

DGCR 8 - dsRNA binding protein part of Microprocessor complex.

Dicer - dsRNA-specificic endonuclease, a member of the RNase III family, which cleaves long dsRNA into 21-25 nucleotide (nt) double stranded fragments.

Drosha - RNase III enzyme part of Microprocessor complex.

EBV - Epstein-Barr virus.

FXMR - Fragile X mental retardation.

H3 Lys9 - Lysine no. 9 in histone 3.

HCMV - Human cytomegalovirus.

Heterochronic gene - Gene which controls the timing of Caenorhabditis elegans larval development.

IgVH locus - Immunoglobulin heavy chain variable region

Interferon response - A cellular response in most mammalian cells to dsRNA longer than 30 base pairs that results in global post-transcriptional gene silencing and usually leads to cell death.

$\mathbf{M}^{7} \mathbf{G}$-cap - 7-methylguanylate cap of the 5'end of nascent RNA transcripts.

Microprocessor - Nuclear enzymatic complex Microprocessor including Drosha and DGCR8

miRNAs - MicroRNAs, endogenous, 21-24nt RNAs that mediate post-transcriptional gene regulation by pairing 
with the 3' untranslated region of mRNAs and acting as translation repressors.

p69 - Virulence factor encoded by turnip yellow mosaic virus, which suppresses the siRNA pathway but promotes the miRNA pathway in Arabidopsis thaliana.

P-bodies - Processing bodies for storage repressed mRNAs, Ago proteins, and miRNAs

PFV-1 - Primate Foamy virus type 1

pre-miRNA - An 65-nt intermediate with stem loop structure

pri-miRNA - Several hundred nucleotides long miRNA precursor

PTGS - Post-transcriptional Gene Silencing. Silencing of an endogenous gene caused by the introduction of a homologous dsRNA, transgene or virus. In PTGS, the transcript of the silenced gene is synthesized but does not accumulate because it is rapidly degraded. This is a more general term than RNAi, since it can be triggered by several different means

RISC - A nuclease complex, composed of proteins and siRNA or miRNA, that targets and destroys mRNAs complementary to the siRNA within the complex or inhibits translation of mRNA partially complementary to miRNA.

RISC* - Active RNA-induced silencing complex including siRNA or miRNA.

RNA interference (RNAi) - Post-transcriptional gene silencing (PTGS) induced by the direct introduction of dsRNA. The term "RNA interference" was first used by researchers studying $C$. elegans.

shRNAs - Short hairpin RNAs, siRNA-like transcripts with stem-loop structure, recognised by DICER as a long dsRNA and processed into siRNA, without interferon response.

siRNAs - Small interfering RNAs, exogenous, 21-23 bp, dsRNA. siRNAs are apparently produced in vivo by cleavage of dsRNA introduced directly or via a transgene or virus. Amplification by an RNA-dependent RNA polymerase (RdRP) may occur in some organisms. siRNAs are incorporated into the RNA-induced silencing complex (RISC), guiding the complex to the homologous endogenous mRNA where the complex cleaves the transcript.

SMA - Spinal muscular atrophy

SMN - Survival of motor neuron gene.

SV40 - Simian virus 40

TuMV - Turnip mosaic virus

UTR - Untranslated region.

\section{REFERENCES}

1. Lee RC, Feinbaum RL, Ambros V. The C. elegans heterochronic gene lin-4 encodes small RNAs with antisense complementarity to lin-14. Cell 1993; 75:843-54.

2. Olsen PH, Ambros V. The lin-4 regulatory RNA controls developmental timing in Caenorhabditis elegans by blocking LIN-14 protein synthesis after the initiation of translation. Dev Biol. 1999; 216:671-80.
3. Wightman B, Ha I, Ruvkun G. Posttranscriptional regulation of the heterochronic gene lin-14 by lin- 4 mediates temporal pattern formation in C. elegans. Cell. 1993; 75:855-62.

4. Reinhart BJ, Slack FS, Basson M, Pasquinelli AE, Bettinger JC, Rougvie AE, Horvitz HR, Ruvkun G. The 21-nucleotide let-7 RNA regulates developmental timing in Caenorhabditis elegans. Nature 2000; 403:901-6.

5. Johnson SM, Grosshans H, Shingara J, Byrom M, Jarvis R, Cheng A, Labourier E, Reinert KL, Brown D, Slack FJ. RAS is regulated by the let-7 microRNA family. Cell 2005; 120:635-47.

6. Pasquinelli AE, Reinhart BJ, Slack F, Martindale MQ, Kuroda M, Maller B, Hayward DC, Ball EE, Degman B, Muller P, Spring J, Srinivasan A, Fisherman M, Finnerty J, Corbo J, Levine M, Davison E, Ruvkun G. Conservation across animal phylogeny of the sequence and temporal regulation of the 21 nucleotide let-7 heterochronic regulatory RNA. Nature 2000; 408:86-9.

7. Lim PL, Glasner M, Yekta ES, Burge CB, Bartel DP. Vertebrate MicroRNA Genes. Science. 2003; 299:1540.

8. He L, Hannon GJ. MicroRNAs: Small RNAs with a big role in gene regulation. Nature 2004; 5:522-31.

9. Grosshans H, Slack FJ. Micro-RNAs: small is plentiful. The Journal of Cell Biology 2002; 156:17-22.

10. Matzke M, Matzke AJM, Kooter JM. RNA:Guiding Gene Silencing. Science 2001; 293:1080-83.

11. Bartel DP. MicroRNAs genomic, biogenesis, mechanism, and function. Cell 2004; 116:281-97.

12. Calin GA, Sevignani C, Dumitru CD, Hyslop T, Noch E, Yendamuri S, Shimizu M, Rattan S, Bullrich F, Negrini M, Croce CM. Human microRNA genes are frequently located at fragile sites and genomic regions involved in cancers. Proc Natl Acad Sci U S A. 2004; 101:2999-3004.

13. He L, Thomson JM, Hemann MT, Hernando-Monge E, Mu D, Goodson S, Powers S, Cordon-Cardo C, Lowe SW, Hannon GJ, Hammond SM. A microRNA polycistron as a potential human oncogene. Nature 2005; 435:828-33.

14. Ying SY, Lin SL. Intronic microRNAs. Biochemical and Biophysical Research Communications 2005; 326:515-20.

15. Cai X, Hagedorn CH, Cullen, BR. Human microRNAs are processed from capped, polyadenylated transcripts that can also function as mRNAs. RNA 2004; 10:1957-66.

16. Lee Y, Kim M, Han J, Yeom KH, Lee S, Back SH, Kim VN. MicroRNA genes are transcribed by RNA polymerase II. EMBO J. 2004; 23:4051-60.

17. Lee Y, Jeon K, Lee JT, Kim S, Kim VN. MicroRNA maturation: stepwise processing and subcellular localization. EMBO J. 2002; 21:4663-70.

18. Gregory RI, Yan KP, Amuthan K, Chendrimada T, Doratotaj B, Cooch N, Shiekhattar R. The Microprocessor complex mediates the genesis of microRNAs. Nature 2004; 432:235-40.

19. Yi R, Qin Y, Macara IG, Cullen BR. Exportin-5 mediates the nuclear export of pre-microRNAs and short hairpin RNAs. Genes and Development 2003; 17:3011-16.

20. Hutvágner G, Zamore PD. A microRNA in a MultipleTurnover RNAi Enzyme Complex. Science 2002; 297:2056-60.

21. Hammond SM, Bersnstein E, Beach D, Hannon GJ. An RNAdirected nuclease mediates post-transcriptional gene silencing in Drosophila cells. Nature 2000; 404:293-96.

22. Martinez J, Tuschl T. RISC is a 5' phosphomonoester-producing RNA endonuclease. Genes Dev. 2004; 18:975-80.

23. Zeng Y, Yi R, Cullen BR. MicroRNAs and small interfering RNAs can inhibit mRNA expression by similar mechanisms. PNAS. 2003; 100:9779-84.

24. Llave J, Tuschl T. RISC is a 5' hosphomonoester-producing RNA endonuclease. Genes and Development 2004; 18:975-80.

25. Schwarz DS, Tomari Y, Zamore PD. The RNA-induced silencing complex is a Mg2+-dependent endonuclease. Curr Biol 2004; 14:787-91.

26. Kern W, Kohlmann A, Wuchter C, Schnittger S, Schoch C, Mergenthaler S, Ratei R, Ludwig WD, Hiddemann W, Haferlach 
T. Correlation of protein expression and gene expression in acute leukemia, Cytometry 2003; 55B:29-36.

27. Llave C, Kasschau KD, Rector MA, Carrington, JC. Endogenous and silencing-associated small RNAs in plants. Plant Cell 2002; 14:1605-19.

28. Lai E, C. Micro RNAs are complementary to 3‘ UTR sequence motifs that mediate negative post-transcriptional regulation. Nature Genetics 2002; 30:363-4.

29. Stark A, Brennecke J, Russell RB, Cohen SM. Identification of Drosophila MicroRNA targets. PLoS Biol. 2003; 1, E60.

30. Wang XJ, Reyes JL, Chua NH, Gaasterland T. Prediction and identification of Arabidopsis thaliana microRNAs and their mRNA targets. Genome Biol. 2004; 5:R65.

31. Ramesh SP, Suvendra A, Bhattacharyya SN, Artus CG, Zoller T, Cougot N, Basyuk E, Bertrand E, Filipowicz W. Inhibition of Translational Initiation by Let-7 MicroRNA in Human Cells. Science 2005; 309:1573-76.

32. Doench JG, Petersen CP, Sharp PA. siRNAs can function as miRNAs. Genes \& Development 2003; 17:438-42.

33. Knight SW, Bass BL. A role for the RNase III enzyme DCR-1 in RNA interference and germ line development in Caenorhabditis elegans. Science 2001; 293:2269-71.

34. Grishok A, Pasquinelli AE, Conte D, Li N, Parrish S, Ha I, Baillie DL, Fire A, Ruvkun G, Mello CC. Genes and mechanisms related to RNA interference regulate expression of the small temporal RNAs that control C. elegans developmental timing. Cell 2001; 106: 23-34.

35. Giraldez AJ, Cinalli RM, Glasner ME, Enright AJ, Thomson JM, Baskerville S, Hammond SM, Bartel DP, Schier AF. MicroRNAs regulate brain morphogenesis in zebrafish. Science 2005; 308:8338.

36. Giraldez AJ, Mishima Y, Rihel J, Grocock RJ, Van Dongen S, Inoue K, Enright AJ, Schier AF. Zebrafish MiR-430 Promotes Deadenylation and Clearance of Maternal mRNAs. Science 2006 Feb 16, 2006 [Epub ahead of print]

37. Xu P, Vernooy SY, Guo M, Hay BA. The Drosophila microRNA Mir-14 suppresses cell death and is required for normal fat metabolism. Curr Biol. 2003; 13:790-5.

38. Houbaviy HB, Murray MF, Sharp PA. Embryonic stem cell-specific MicroRNAs. Dev Cell. 2003; 5:351-8.

39. Krichevsky AM, King KS, Donahue CP, Khrapko K, Kosik KS. A microRNA array reveals extensive regulation of microRNAs during brain development. RNA 2003; 9:1274-81.

40. Liu CG, Calin GA, Meloon B, Gamliel N, Sevignani C, Ferracin M, Dumitru CD, Shimizu M, Zupo S, Dono M, Alder H, Bullrich F, Negrini M, Croce CM. An oligonucleotide microchip for genomewide microRNA profiling in human and mouse tissues. PNAS 2004; 101:9740-4.

41. Sempere LF, Freemantle S, Pitha-Rowe I, Moss E, Dmitrovsky E, Ambros V. Expression profiling of mammalian microRNAs uncovers a subset of brain-expressed microRNAs with possible roles in murine and human neuronal differentiation. Genome Biol. 2004; $5, \mathrm{R} 13$.

42. Wassenegger M, Heimes S, Riedel L, Sanger HL. RNA-directed de novo methylation of genomic sequences in plants. Cell 1994; 76, 567-76.

43. Grewal SIS, Rice JC. Regulation of heterochromatin by histone methylation and small RNAs. Current Opinion in Cell Biology 2004; 16:230-38.

44. Volpe TA, Kidner C, Hall IM, Teng G, Grewal SI, Martienssen RA. Regulation of heterochromatic silencing and histone H3 lysine-9 methylation by RNAi. Science 2002; 297:1818-9.

45. Hall IH, Shankaranarayana GD, Noma K, Ayoub N, Cohen A, Grewal SI. Establishment and maintenance of a heterochromatin domain. Science 2002; 297:2215-8.

46. Sullivan CS, Ganem D. MicroRNAs and viral infection. Mol Cell. 2005; 20:3-7.

47. Li HW, Ding SW. Antiviral silencing in animals. FEBS Lett. 2005; 579:5965-73.

48. Christopher S, Sullivan CS, Grundhoff AT, Tevethia S, Pipas JM, Ganem D. SV40-encoded microRNAs regulate viral gene expres- sion and reduce susceptibility to cytotoxic T cells. Nature 2005; 435:682-86.

49. Pfeffer S, Zavolan M, Grässer FA, Chien M, Russo JJ, Ju J, John B, Enright AJ, Marks D, Sander C, Tuschl T. Identification of Virus-Encoded MicroRNAs. Science 2004; 304:734-6.

50. Dunn W, Trang P, Zhong Q, Yang E, Belle C, Liu F. Human cytomegalovirus expresses novel microRNAs during productive viral infection. Cellular Microbiology 2005; 7:1684-95.

51. Grey F, Antoniewicz A, Allen E, Saugstad J, McShea A, Carrington JC, Nelson J. Identification and Characterization of Human Cytomegalovirus-Encoded MicroRNAs. J.Virol. 2005; 79:1209599.

52. Bennasser Y, Le SY, Yeung M L, Jeang K T. HIV-1 encoded candidate micro-RNAs and their cellular targets. Retrovirology 2004; $1(1): 43$.

53. Cai X, Lu S, Zhang Z, Gonzalez CM, Damania B, Cullen BR. Kaposi's sarcoma-associated herpesvirus expresses an array of viral microRNAs in latently infected cells. PNAS. 2005; 102: 5570-5.

54. Lecellier C, H, Dunoyer P, Arar K, Lehmann C, J, Eyquem S, Himber C, Saib A, Voinnet O. A cellular microRNA mediates antiviral defense in human cells. Science 2005; 308:557-60.

55. Kasschau KD, Xie Z, Allen E, Llave C, Chapman E, J, Krizan KA, Carrington JC. P1/HC-Pro, a Viral Suppressor of RNA Silencing, Interferes with Arabidopsis Development and miRNA Function. Cell 2003; 4:205-17.

56. Chen J, Li W, X, Xie D, Peng JR, Ding SW. Viral Virulence Protein Suppresses RNA Silencing-Mediated Defense but Upregulates the Role of MicroRNA in Host Gene Expression. The Plant Cell 2004; 16:1302-13.

57. Chellallan P, Vanitharani R, Frauquet CM. MicroRNA-binding viral protein interferes with Arabidopsis development. PNAS. 2005; 102:10381-86.

58. Lu S, Cullen BR. Adenovirus VA1 Noncoding RNA Can Inhibit Small Interfering RNA and MicroRNA Biogenesis. Journal of Virology 2004; 78:12868-76.

59. Dostie J, Mourelatos Z, Yang M, Sharma A, Dreyfuss G. Numerous microRNPs in neuronal cells containing novel microRNAs. $R N A$ 2003; 9:180-6.

60. Ishizuka A, Siomi M, C, Siomi H. A Drosophila fragile X protein interacts with components of RNAi and ribosomal proteins. Genes Dev. 2002; 16:2497-508.

61. Shiohama A, Sasaki T, Noda N, Minoshima S, Shimizu N. Molecular cloning and expression analysis of a novel gene DGCR8 located in the DiGeorge syndrome chromosomal region. Biochem Biophys Res Commun. 2003; 304:184-90.

62. Poy MN, Eliasson L, Krutzfeldt J, Kuwajima S, Ma X, Macdonald PE, Pfeffer S, Tuschl T, Rajewsky N, Rorsman P, Stoffel M. A pancreatic islet-specific microRNA regulates insulin secretion. Nature 2004; 432:226-30.

63. Lu J, Getz G, Miska EA, Alvarez-Saavedra E, Lamb J, Peck D, Sweet-Cordero A, Ebert BL, Mak RH, Ferrando AA, Downing JR, Jacks T, Horvitz HR, Golub TR. MicroRNA expression profiles classify human cancers. Nature 2005; 435:834-8.

64. Bigoni R, Cuneo A, Roberti MG, Bardi A, Rigolin GM, Piva N, Scapoli G, Spanedda R, Negrini M, Bullrich F, Veronese ML, Croce CM, Castoldi G. Chromosome aberrations in atypical chronic lymphocytic leukemia: a cytogenetic and interphase cytogenetic study. Leukemia 1997; 11:1933-40.

65. Desikan R, Barlogie B, Sawyer J, Ayers D, Tricot G, Badros A, Zangari M, Munshi NC, Anaissie E, Spoon D, Siegel D, Jagannath S, Vesole D, Epstein J, Shaughnessy J, Fassas A, Lim S, Roberson P, Crowley J. Results of high-dose therapy for 1000 patients with multiple myeloma: durable complete remissions and superior survival in the absence of chromosome 13 abnormalities. Blood 95: 2000; 4008-10.

66. Dohner H, Stilgenbauer S, Dohner K, Bentz M, Lichter P. Chromosome aberrations in B-cell chronic lymphocytic leukemia: reassessment based on molecular cytogenetic analysis. J Mol Med. 1999; 77:266-81.

67. Stilgenbauer S, Nickolenko J, Wilhelm J, Wolf S, Weitz S, Dohner $\mathrm{K}$, Boehm T, Dohner H, Lichter P. Expressed sequences as can- 
didates for a novel tumor suppressor gene at band $13 \mathrm{q} 14$ in Bcell chronic lymphocytic leukemia and mantle cell lymphoma. Oncogene 1998; 6:1891-7.

68. Calin GA, Dumitru CD, Shimizu M, Bichi R, Zupo S, Noch E, Aldler H, Rattan S, Keating M, Rai K, Rassenti L, Kipps T, Negrini $\mathrm{M}$, Bullrich F, Croce CM. Frequent deletions and down-regulation of microRNA genes miR15 and miR16 at 13q14 in chronic lymphocytic leukemia. Proc Natl Acad Sci U S A. 2002; 99:15524-9.

69. Lagos-Quintana M, Rauhut R, Yalcin A, Meyer J, Lendeckel W, Tuschl T. Identification of tissue-specific microRNAs from mouse. Curr Biol. 2002; 12:735-9.

70. Cimmino A, Calin GA, Fabbri M, Iorio MV, Ferracin M, Shimizu M, Wojcik SE, Aqeilan RI, Zupo S, Dono M, Rassenti L, Alder H, Volinia S, Liu CG, Kipps TJ, Negrini M, Croce CM. miR-15 and miR-16 induce apoptosis by targeting BCL2. Proc Natl Acad Sci U S A. 2005; 102:13944-9.

71. Calin GA, Liu CG, Sevignani C, Ferracin M, Felli N, Dumitru CD, Shimizu M, Cimmino A, Zupo S, Dono M, Dell'Aquila ML, Alder H, Rassenti L, Kipps TJ, Bullrich F, Negrini M, Croce CM MicroRNA profiling reveals distinct signatures in B cell chronic lymphocytic leukemias. Proc Natl Acad Sci U S A. 2004; 101: 11755-60.

72. Juliusson G, Oscier DG, Fitchett M, Ross FM, Stockdill G, Mackie MJ, Parker AC, Castoldi GL, Guneo A, Knuutila S, Elonen E, Gahrton G. Prognostic subgroups in B-cell chronic lymphocytic leukemia defined by specific chromosomal abnormalities. N Engl J Med. 1990; 323:720-4.

73. Oscier DG, Gardiner AC, Mould SJ, Glide S, Davis ZA, Ibbotson RE, Corcoran MM, Chapman RM, Thomas PW, Copplestone JA, Orchard JA, Hamblin TJ. Multivariate analysis of prognostic factors in CLL: clinical stage, IGVH gene mutational status, and loss or mutation of the $\mathrm{p} 53$ gene are independent prognostic factors. Blood 2002; 100:1177-84.

74. Orchard JA, Ibbotson RE, Davis Z, Wiestner A, Rosenwald A, Thomas PW, Hamblin TJ, Staudt LM, Oscier DG. ZAP-70 expression and prognosis in chronic lymphocytic leukaemia. Lancet 2004 363:105-11.

75. Wiestner A, Rosenwald A, Barry TS, Wright G, Davis RE, Henrickson SE, Zhao H, Ibbotson RE, Orchard JA, Davis Z, Stetler-Stevenson M, Raffeld M, Arthur DC, Marti GE, Wilson WH, Hamblin TJ, Oscier DG, Staudt LM. ZAP-70 expression identifies a chronic lymphocytic leukemia subtype with unmutated immunoglobulin genes, inferior clinical outcome, and distinct gene expression profile. Blood 2003; 101:4944-51.

76. Calin GA, Ferracin M, Cimmino A, Di Leva G, Shimizu M, Wojcik SE, Iorio MV, Visone R, Sever NI, Fabbri M, Iuliano R, Palumbo T, Pichiorri F, Roldo C, Garzon R, Sevignani C, Rassenti L, Alder H, Volinia S, Liu CG, Kipps TJ, Negrini M, Croce CM. A MicroRNA signature associated with prognosis and progression in chronic lymphocytic leukemia. N Engl J Med. 2005; 353:1793-801.

77. Eis PS, Tam W, Sun L, Chadburn A, Li Z, Gomez MF, Lund E, Dahlberg JE. Accumulation of miR-155 and BIC RNA in human B cell lymphomas. Proc Natl Acad Sci U S A. 2005; 102: 3627-32.

78. Knuutila S, Bjorkqvist AM, Autio K, Tarkkanen M, Wolf M, Monni O, Szymanska J, Larramendy ML, Tapper J, Pere H, El-Rifai W, Hemmer S, Wasenius VM, Vidgren V, Zhu Y. DNA copy number amplifications in human neoplasms: review of comparative genomic hybridization studies. Am J Pathol. 1998; 152:1107-23.

79. Ota A, Tagawa H, Karnan S, Tsuzuki S, Karpas A, Kira S, Yoshida Y, Seto M. Identification and characterization of a novel gene, C13orf25, as a target for 13q31-q32 amplification in malignant lymphoma. Cancer Res. 2004; 64:3087-95.

80. O’Donnell KA, Wentzel EA, Zeller KI, Dang CV, Mendell JT. c-Myc-regulated microRNAs modulate E2F1 expression. Nature $2005 ; 435: 839-43$.
81. Hayashita Y, Osada H, Tatematsu Y, Yamada H, Yanagisawa K, Tomida S, Yatabe Y, Kawahara K, Sekido Y, Takahashi T. A polycistronic microRNA cluster, miR-17-92, is overexpressed in human lung cancers and enhances cell proliferation. Cancer Res. 2005; 65:9628-32.

82. Gauwerky CE, Huebner K, Isobe M, Nowell PC, Croce CM. Activation of MYC in a masked $t(8 ; 17)$ translocation results in an aggressive B-cell leukemia. Proc Natl Acad Sci U S A. 1989; $86: 8867-71$.

83. Chen C, Z, Li L, Lodish HF, Bartel DP. MicroRNAs modulate hematopoietic lineage differentiation. Science 2004; 303:83-6.

84. Michael MZ, O' Connor SM, van Holst Pellekaan NG, Young GP, James RJ. Reduced accumulation of specific microRNAs in colorectal neoplasia. Mol Cancer Res. 2003; 1:882-91.

85. Iorio MV, Ferracin M, Liu CG, Veronese A, Spizzo R, Sabbioni S, Magri E, Pedriali M, Fabbri M, Campiglio M, Menard S, Palazzo JP, Rosenberg A, Musiani P, Volinia S, Nenci I, Calin GA, Querzoli $\mathrm{P}$, Negrini M, Croce CM. MicroRNA gene expression deregulation in human breast cancer. Cancer Res. 2005; 65:7065-70.

86. Negrini M, Rasio D, Hampton GM, Sabbioni S, Rattan S, Carter SL, Rosenberg AL, Schwartz GF, Shiloh Y, Cavenee WK. Definition and refinement of chromosome 11 regions of loss of heterozygosity in breast cancer: identification of a new region at 11q23.3. Cancer Res. 1995; 55:3003-7.

87. Rasio D, Negrini M, Manenti G, Dragani TA, Croce CM. Loss of heterozygosity at chromosome $11 \mathrm{q}$ in lung adenocarcinoma: identification of three independent regions. Cancer Res. 1995; 55:3988-91.

88. Lee YS, Kim HK, Chung S, Kim KS, Dutta A. Depletion of human micro-RNA miR-125b reveals that it is critical for the proliferation of differentiated cells but not for the down-regulation of putative targets during differentiation. J Biol Chem 2005; 280:16635-41.

89. Takamizawa J, Konishi H, Yanagisawa K, Tomida S, Osada H, Endoh H, Harano T, Yatabe Y, Nagino M, Nimura Y, Mitsudomi T, Takahashi T. Reduced expression of the let-7 microRNAs in human lung cancers in association with shortened postoperative survival. Cancer Res. 2004; 64:3753-6.

90. Yanaihara N, Caplen N, Bowman E, Seike M, Kumamoto K, Yi M, Stephens RM, Okamoto A, Yokota J, Tanaka T, Calin GA, Liu CG, Croce CM, Harris CC. Unique microRNA molecular profiles in lung cancer diagnosis and prognosis. Cancer Cell. 2006; 9:189-98.

91. Johnson SM, Grosshans H, Shingara J, Byrom M, Jarvis R, Cheng A, Labourier E, Reinert KL, Brown D, Slack FJ. RAS is regulated by the let-7 microRNA family. Cell 2005; 120:635-47.

92. Karube Y, Tanaka H, Osada H, Tomida S, Tatematsu Y, Yanagisawa K, Yatabe Y, Takamizawa J, Miyoshi S, Mitsudomi T, Takahashi T. Reduced expression of Dicer associated with poor prognosis in lung cancer patients.Cancer Sci. 2005; 96:111-5.

93. Ciafre SA, Galardi S, Mangiola A, Ferracin M, Liu CG, Sabatino G, Negrini M, Maira G, Croce CM, Farace MG. Extensive modulation of a set of microRNAs in primary glioblastoma. Biochem Biophys Res Commun. 2005; 334:1351-8.

94. Chan JA, Krichevsky AM, Kosik KS. MicroRNA-21 is an antiapoptotic factor in human glioblastoma cells. Cancer Res. 2005; 66: 6029-33.

95. Holland EC. Gliomagenesis: genetic alterations and mouse models. Nat Rev Genet. 2001; 2:120-9.

96. Zhu Y, Parada LF. The molecular and genetic basis of neurological tumours. Nat Rev Cancer. 2002; 2:616-26.

97. Weber MJ. New human and mouse microRNA genes found by homology search. FEBS J. 2005; 272:59-73. 